Teknik, 38 (1), 2017, 28-34

\title{
Pengaruh Desa Wisata Kampoeng Batik Laweyan Terhadap Fungsi Permukiman Di Kelurahan Laweyan Kota Surakarta
}

\author{
Eva Artmey Mangedaby ${ }^{*}$, Bambang Setioko, Suzanna Ratih Sari \\ Program Pascasarjana, Magister Teknik Arsitektur, Universitas Diponegoro, \\ Jl. Prof. Soedarto, SH, Kampus Undip Tembalang, Semarang, Indonesia 50275
}

\begin{abstract}
Abstrak
Kawasan Kampoeng batik Laweyan, yang merupakan salah satu daerah tujuan wisata popular di Surakarta, mengalami perubahan. Hal ini terlihat tidak hanya dari bentuk dan tata ruang rumah di Kampoeng batik Laweyan tapi juga di Kelurahan Laweyan. Perubahan ini mengakibatkan tidak tersedianya ruang terbuka hijau di Kelurahan Laweyan. Paper ini memuat hasil penelitian yang bertujuan untuk menentukan seberapa besar pengaruh Desa Wisata Kampoeng Batik Laweyan terhadap fungsi permukiman di Kelurahan Laweyan. Metode penelitian yang digunakan adalah metode kuantitatif dengan pendekatan korelasi. Proses penelitian ini melalu tiga tahapan yaitu kompilasi data, pemberian kode variabel, dan pengolahan data dengan analisis regresi linear berganda menggunakan uji SPSS. Hasil penelitian menunjukkan bahwa Desa Wisata Kampoeng Batik Laweyan mempengaruhi fungsi permukiman di Kelurahan Laweyan Kota Surakarta sebesar 81,6\% sedangkan sisanya 18,4\% dipengaruhi oleh faktor lain di luar model. Pengaruh ini berupa perubahan fungsi permukiman di Kelurahan Laweyan menjadi hunian dan juga tempat usaha, penambahan fasilitas pendukung wisata lainnya, dan juga penambahan street furniture yang menjadi ciri khas desa wisata. Faktor lain di luar model yang memperngaruhi adalah sejarah kawasan dan perubahan tata guna lahan. Peran stake holder yang terkait seperti pemerintah, swasta, dan masyarakat sangat diperlukan dalam pengembangan desa wisata ini. Pemerintah berperan sebagai pengelola dan fasilitator, swasta sebagai pembantu pelaksana program pemerintah, sedangkan masyarakat bisa berpartisipasi secara aktif mendukung program yang ditetapkan.
\end{abstract}

Kata kunci: Kampoeng Batik; Desa Wisata; Permukiman; Fungsi Permukiman

\begin{abstract}
[Title: The Impact of Laweyan Batik Kampoeng Tourism Village to Settlement Function in Laweyan District Surakarta] Kampoeng Batik Laweyan located in Laweyan has changed. Being a popular tourism object, Kampoeng Batik Laweyan has influenced the settlement area in Laweyan Village, not only the shapes but also the house arrangement. This changing causes no more green space in the village. This paper presents research results in determining the impact of the tourism village to the settlement function in laweyan village. Quantitative method with correlation approach is used in this research which are conducted through three steps: data compilation, code variable, and data processing through linear regression multiple analysis using SPSS test. The results show that Kampoeng Batik Laweyan influences the settlement function by $81.6 \%$ while the rest $18.4 \%$ was affected by other factors beyond the model. The village has changed the settlement function to both as a house and a home industry, the provision of tourism facilities, and also addition of street furnitures which becomes the signature tourism village. Other influencing factors were the history of the area land use law. The role of stakeholders such as government, private sector and community members are needed for the tourism village development. The government has functions to manage and facilitate developmenet programs, while private sectors, and community members support the implementation.
\end{abstract}

Keywords: Kampoeng Batik; Tourism Village; Settlement; Settlement Function

\section{Pendahuluan}

Perkembangan kota merupakan perubahan yang terjadi pada kota baik perubahan-perubahan yang dikehendaki melalui berbagai perencanaan kota,

\footnotetext{
${ }^{*}$ Penulis Korespondensi.

E-mail: eva.artmeym@gmail.com
}

maupun perkembangan yang sifatnya organis yang berkembang dengan sendirinya (Bintarto, 1983). Perencanaan kota yang dimaksud adalah berupa segala bentuk intervensi pemerintah dalam ikut 


\section{Teknik, 38 (1), 2017, 29}

serta mengatur perkembangan kota yang wujudnya dituangkan dalam konsep tata ruang kota.

Perkembangan permukiman di perkotaan merupakan bagian dari perkembangan perkotaan secara keseluruhan yang dipengaruhi oleh perkembangan berbagai faktor seperti ekonomi, sosial, budaya, teknologi dan keadaan alam (Yudohusodo, 1991). Dengan semakin tingginya tingkat perkembangan/ pertumbuhan permukiman kota, maka tingkat pemenuhan akan kebutuhan fisik maupun non fisik kota akan semakin meningkat. Pembangunan perumahan (biasanya) sebagai pioneer/pemicu aktivitas yang akan diikuti pergerakan aktivitas penunjang lain kearahnya.

Pengalokasian guna lahan di perkotaan akan mengarah ke lokasi yang dapat memberikan keuntungan tertinggi, sehingga lahan-lahan yang memiliki nilai strategis dan potensi yang lebih besar akan lebih berpeluang mengalami proses perubahan pemanfaatan lahan. Pada umumnya gejala ini terjadi di jalan-jalan utama atau kawasan-kawasan tertentu yang memiliki keunikan dan karakteristik tersendiri (Hadi, 2000).

Kegiatan ekonomi merupakan hal yang penting bagi suatu kota karena merupakan dasar agar kota dapat bertahan dan berkembang (Jayadinata, 1992). Kedudukan aktifitas ekonomi sangat penting sehingga seringkali menjadi basis perkembangan sebuah kota. Adanya berbagai kegiatan ekonomi dalam suatu kawasan menjadi potensi perkembangan kawasan tersebut pada masa berikutnya. Berkaitan dengan fungsi kota sebagai pusat komersial, kawasan pusat perdagangan / usaha (Central Business District /CDB), adalah tempat pusat kegiatan perdagangan kota yang berpengaruh besar terhadap tingkat ekonomi kota dan letaknya tidak selalu di tengah tengah kota. Untuk kota - kota besar biasanya mempunyai lebih dari satu kawasan pusat perdagangan (Direktorat Jenderal Cipta Karya,1998).

Kota Surakarta merupakan salah satu sentra produksi batik di Jawa Tengah yang terkenal karena batik berkualitas baik yang ditawarkan, selain itu Kota Surakarta memiliki produk unggulan dan kebanggaan tersendiri yang pada dasarnya adalah salah satu warisan budaya dunia. Sejak tahun 1911 Kampoeng Batik Laweyan Solo ini menjadi bukti masa keemasan Serikat Dagang Islam oleh KH Samanhudi, dan semakin hari popularitasnya semakin meningkat seiring dengan diperkenalkannya hasil kerajinan batik dari Solo ke mata Internasional. Saat ini, Kampoeng batik Laweyan sedang dipersiapkan oleh pemerintah Kota Solo sebagai desa wisata agar bisa menarik wisatawan. Kampoeng batik laweyan didesain dengan konsep terpadu dengan memanfaatkan lahan seluas kurang dari $24 \mathrm{Ha}$ yang terdiri dari 3 blok.

Sebagai Kampoeng batik yang saat ini tengah populer membuat kawasan permukiman di Kelurahan Laweyan juga mengalami perubahan, hal ini terlihat dari bentuk dan tata ruang rumah itu sendiri, yang awalnya sebagai tempat tinggal dan sebagai tempat showroom batik saat ini sudah melebar menjadi ruang untuk produksi. Perubahan ini tidak hanya terjadi pada Kampoeng batik Laweyan saja tetapi satu Kelurahan Laweyan. Untuk menunjang aktifitas berbelanja dan wisata para wisatawan maka banyak rumah yang beralih fungsi sebagai warung/ruko, kos, hotel, restoran serta lahan parkir.

Kampoeng batik yang terletak di Kelurahan Laweyan ini tengah marak di Indonesia merupakan salah satu daerah tujuan pariwisata yang selanjutnya disebut destinasi pariwisata. Dalam Undang-Undang No. 10 tahun 2009 tentang Kepariwisataan (Republik Indonesia, 2009), disebutkan bahwa destinasi wisata adalah kawasan geografis yang berada dalam satu atau lebih wilayah administratif yang di dalamnya terdapat daya tarik wisata, fasilitas umum, fasilitas pariwisata, aksesibilitas, serta masyarakat yang saling terkait dan melengkapi terwujudnya kepariwisataan. Adisasmita (2010) menjelaskan bahwa jenis wisata itu sendiri sangat beraneka ragam, salah satunya adalah wisata alternatif yang merupakan suatu bentuk wisata yang sengaja disusun dalam skala kecil, memperhatikan kelestarian lingkungan dan segi-segi sosial. Bentuk wisata ini sengaja diciptakan sebagai tandingan terhadap bentuk pariwisata yang umumnya berskala besar.

Menurut Rencana Tata Ruang dan Wilayah (RTRW) Kota Surakarta Tahun 2011-2031 (Pemerintah Daerah Surakarta, 2012) peruntukan kawasan di Kecamatan Laweyan Kota Surakarta sebagai industri kreatif, pariwisata cagar budaya, sejarah dan nilai-nilai tradisional, sebagai pariwisata belanja, dan kawasan permukiman berkepadatan tinggi. Kondisi eksisting Laweyan yaitu di Jalan Dr. Radjiman adalah sebagai perdagangan dan jasa serta perkantoran. Hal ini menyebabkan Laweyan semakin padat. Tidak sedikit bangunan yang menjadikan tempat tinggal sekaligus sebagai tempat usaha, hal ini mengakibatkan permukiman di Kelurahan Laweyan sangat padat dan tidak ada lagi tersedianya lahan kosong untuk Ruang Terbuka Hijau.

Paper ini menyajikan hasil penelitian yang bertujuan untuk menentukan seberapa besar pengaruh Desa Wisata Kampoeng Batik Laweyan terhadap perubahan fungsi permukiman di Kelurahan Laweyan.

\section{Metode Penelitian}

Metode penelitian yang digunakan adalah metode kuantitatif dengan pendekatan korelasi memakai analisis likerts serta analisis skoring berdasarkan asumsi yang sudah ditetapkan kemudian di uji dengan analisis regresi linear berganda menggunakan uji SPSS. Penelitian ini menggunakan 9 variabel dan 19 pertanyaan (Tabel 1). Teknik analisis data dalam penelitian ini menggunakan statistik deskriprif untuk mengambil kesimpulan dari sampel yang diuji. Proses penelitian ini melalu tiga 
tahapan yaitu kompilasi data, pemberian kode variabel dan pengolahan data dengan analisis regresi.

Tabel 1 Pemberian Kode Variabel

\begin{tabular}{|c|c|}
\hline Variabel/ Indikator & Kode \\
\hline Desa Wisata & $\mathbf{X}$ \\
\hline Accesbility & $\mathbf{X 1}$ \\
\hline Fasilitas transportasi & $\mathrm{X} 1.1$ \\
\hline Pelayanan transportasi & $\mathrm{X} 1.2$ \\
\hline Jarak tempuh & $\mathrm{X} 1.3$ \\
\hline Attraction & $\mathbf{X} 2$ \\
\hline Setting fisik lokasi desa wisata & $\mathrm{X} 2.1$ \\
\hline Kegiatan menarik di desa wisata & $\mathrm{X} 2.2$ \\
\hline Kebudayaan menarik di desa wisata & $\mathrm{X} 2.3$ \\
\hline Amenity & $\mathbf{X 3}$ \\
\hline $\begin{array}{l}\text { Ketersediaan sarana akomodasi seperti hotel, } \\
\text { guesthouse, motel }\end{array}$ & $\mathrm{X} 3.1$ \\
\hline $\begin{array}{l}\text { Ketersediaan restaurant (tempat makan dan } \\
\text { minum) }\end{array}$ & $\mathrm{X} 3.2$ \\
\hline Ketersediaan toilet umum & $\mathrm{X} 3.3$ \\
\hline Ketersediaan rest area & $\mathrm{X} 3.4$ \\
\hline Ketersediaan tempat parkir & $\mathrm{X} 3.5$ \\
\hline Ketersediaan klik kesehatan & $\mathrm{X} 3.6$ \\
\hline Ketersediaan tempat ibadah & $\mathrm{X} 3.7$ \\
\hline Ketersediaan toko kelontong & $\mathrm{X} 3.8$ \\
\hline Ancilliary & $\mathbf{X 4}$ \\
\hline $\begin{array}{l}\text { Ketersediaan kelembagaan untuk mengelola } \\
\text { kegiatan wisata }\end{array}$ & $\mathrm{X} 4.1$ \\
\hline $\begin{array}{l}\text { Ketersediaan aturan-aturan atau norma agama } \\
\text { yang menjadi mayoritas dan sistem } \\
\text { kepercayaan }\end{array}$ & $\mathrm{X} 4.2$ \\
\hline Activity & $\mathbf{X 5}$ \\
\hline $\begin{array}{l}\text { Ketersediaan aktifitas wisatawan di tempat } \\
\text { wisata }\end{array}$ & $\mathrm{X} 5.1$ \\
\hline $\begin{array}{l}\text { Ketersediaan aktifitas masyarakat di tempat } \\
\text { wisata }\end{array}$ & $\mathrm{X} 5.2$ \\
\hline $\begin{array}{c}\text { Fungsi Permukiman } \\
\end{array}$ & $\mathbf{Y}$ \\
\hline Ruang Interaksi Sosial & Y1 \\
\hline Ketersediaan Balai Desa/balai pertemuan & Y1.1 \\
\hline $\begin{array}{lllll}\begin{array}{l}\text { Ketersediaan taman/ ruang terbuka hijau/ } \\
\text { lapangan }\end{array} & & & \\
\end{array}$ & Y1.2 \\
\hline Ruang Atraksi Wisata & Y2 \\
\hline Ketersediaan ruang untuk membatik & $\mathrm{Y} 2.1$ \\
\hline Ketersediaan ruang untuk atraksi kebudayaan & Y2.2 \\
\hline Ruang Aktifitas & Y3 \\
\hline Ketersediaan rumah sebagai hunian & Y3.1 \\
\hline Ketersediaan rumah sebagai tempat usaha & Y3.2 \\
\hline $\begin{array}{l}\text { Ketersediaan rumah sebagai hunian dan tempat } \\
\text { usaha }\end{array}$ & Y3.3 \\
\hline Ruang Pendukung Wisata & Y4 \\
\hline Ketersediaan ruang untuk berolahraga & Y4.1 \\
\hline $\begin{array}{l}\text { Ketersediaan jaringan jalan, drainase, air } \\
\text { bersih, telepon, dan listrik }\end{array}$ & Y4.2 \\
\hline $\begin{array}{llll}\begin{array}{l}\text { Ketersediaan } \\
\text { pemerintahan }\end{array} & \text { pelayanan } & \text { umum } & \text { dan } \\
\end{array}$ & Y4.3 \\
\hline Ketersediaan bank dan atm & Y4.4 \\
\hline
\end{tabular}

\section{Hasil dan Pembahasan}

3.1 Gambaran Umum dan Data

Kelurahan Laweyan merupakan Kelurahan yang terletak di Kecamatan Laweyan Kota Surakarta dengan potensi sebagai desa wisata. Kelurahan Laweyan terbagi atas $3 \mathrm{RW}$ dan $10 \mathrm{RT}$ dengan luas wilayah 4,2 Ha seperti diilustrasikan di Gambar 1.

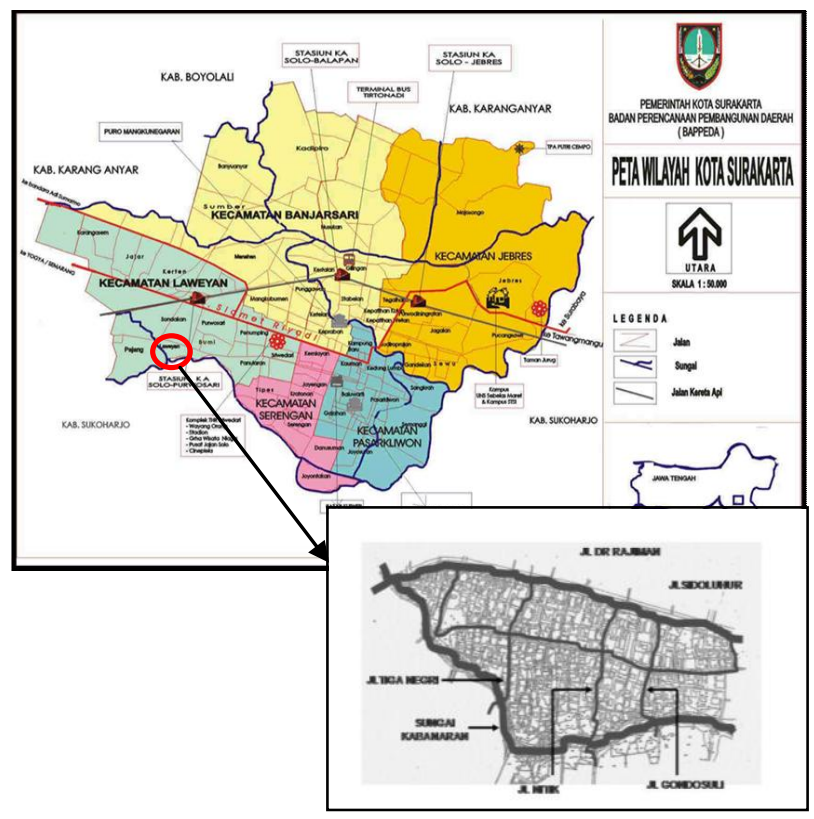

Gambar 1 Tautan Wilayah Kelurahan Laweyan

Sumber: Bappeda Kota Surakarta, 2016

\subsubsection{Arsitektur Bangunan Rumah Laweyan}

Masyarakat Laweyan bukanlah keturunan bangsawan, tetapi karena mempunyai hubungan yang erat dengan kraton melalui perdagangan batik serta didukung dengan kekayaan yang ada, maka corak pemukiman khususnya milik para saudagar batik banyak dipengaruhi oleh corak pemukiman bangsawan Jawa. Bangunan rumah saudagar biasanya terdiri dari pendopo, ndalem, sentong, gandok, paviliun, pabrik, beteng, regol, halaman depan rumah yang cukup luas dengan orientasi bangunan menghadap utara-selatan. Atap bangunan kebanyakan menggunakan atap limasan bukan joglo karena bukan keturunan bangsawan.

Di Kampoeng Batik Kelurahan Laweyan terdapat 434 rumah. Rumah yang difungsikan sebagai hunian sejumlah 268 unit, rumah yang difungsikan sebagai tempat usaha 22 unit, dan rumah yang difungsikan ganda sebagai hunian dan tempat usaha sebanyak 144 unit dengan sisa jumlah tanah kosong $2 \%$.

\subsubsection{Sarana Penunjang Wisata}

Sarana perdagangan dan jasa yang ada di kelurahan Laweyan adalah beragam yang didominasi oleh showroom batik, sebagaimana yang ditampilkan Tabel 2. 
Teknik, 38 (1), 2017, 31

Tabel 2 Jumlah Sarana Perdagangan dan Jasa di Kelurahan Laweyan Tahun 2016

\begin{tabular}{|c|l|c|}
\hline No & \multicolumn{1}{|c|}{ Sarana Perdagangan } & Jumlah \\
\hline 1 & Warung Kelontong & 24 \\
\hline 2 & Showroom Batik & 84 \\
\hline 3 & Toko, dealer, bengkel, kursus & 29 \\
\hline & $\begin{array}{l}\text { Warung makan, rumah makan, } \\
\text { kuliner }\end{array}$ & 20 \\
\hline 5 & Kos-kosan & 3 \\
\hline 6 & Hotel & 2 \\
\hline 7 & Gedung Pertemuan & 3 \\
\hline
\end{tabular}

Sumber: Data Monografi Kelurahan Laweyan, 2016

3.1.3 Perubahan tatanan Ruang Rumah di Kelurahan Laweyan

Laweyan terdiri dari pabrik untuk produksi batik di belakang rumah yang luas, sentong yang berarti bilik atau kamar, gendok yang berarti bangunan yang menempel diruang utama yang juga di fungsikan sebagai ruang tengah, serta pendopo. Terdapat pintu belakang rumah yang difungsikan untuk para pekerja pabrik batik melakukan pergerakan. Pintu dan pagar rumah dibangun megah dan tinggi seperti benteng hal ini memiliki filosofi untuk memperoleh keamanan dan untuk menjaga privacy para saudagar batik serta memperoleh daerah "kekuasaan" di lingkungan komunitasnya. Gambar 2 menunjukkan peletakan ruang pada rumah bergaya indis di Kelurahan laweyan pada abad ke 18.

Saat ini tatanan ruang untuk showroom batik tidak cukup hanya di satu ruang tetapi membutuhkan beberapa ruang yang cukup luas. Ini dikarenakan produksi batik yang dihasilkan masyarakat Kampoeng Batik Laweyan sangat banyak untuk memenuhi permintaan pasar. Selain itu Kampoeng Batik Laweyan tidak hanya memproduksi kain batik tetapi juga pakaian jadi dengan bahan batik seperti kemeja, rok, gaun yang di modifikasi, sandal, tas, kalung, topi hingga dompet Sketsa rumah batik saat ini tampak pada Gambar 3.

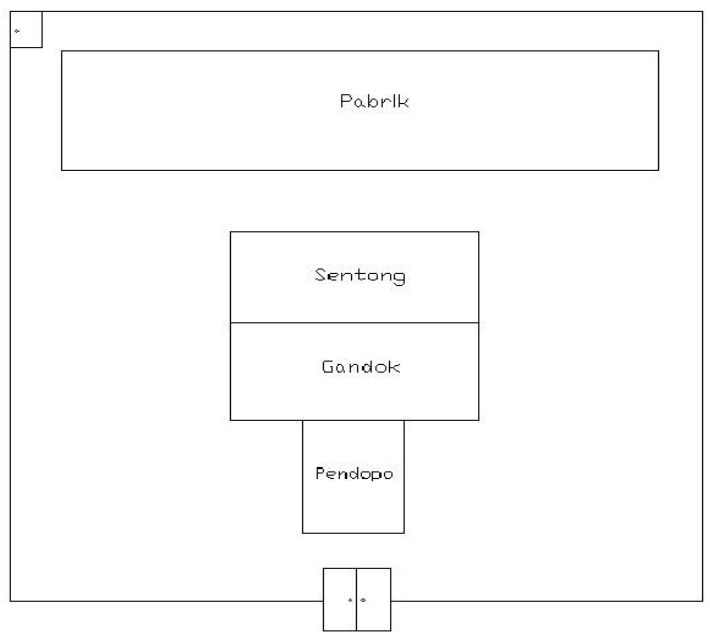

Gambar 2 Sketsa rumah produsen batik pada abad 18

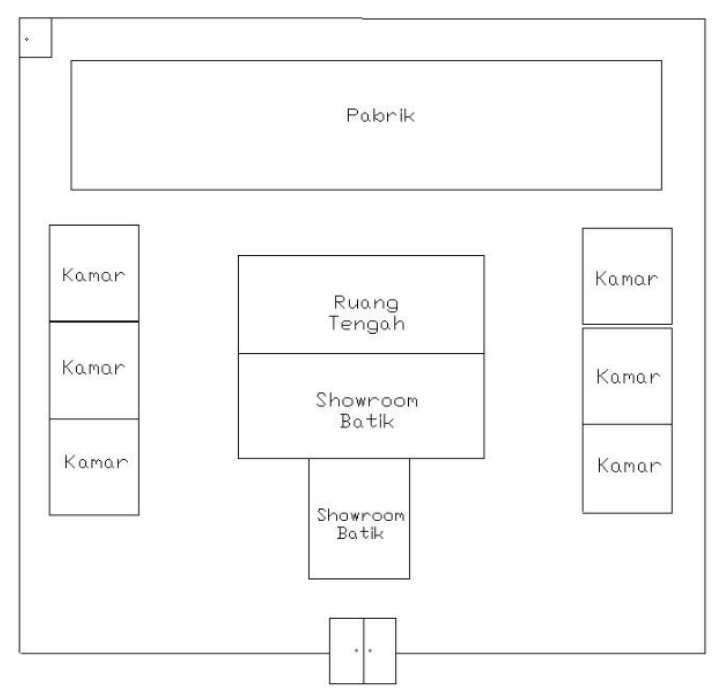

Gambar 3 Sketsa rumah produsen batik saat ini

\subsubsection{Gambaran Umum Responden}

Penelitian ini melibatkan responden yang memiliki variasi kelompok umur. Karakteristik responden tampak pada Gambar 4.

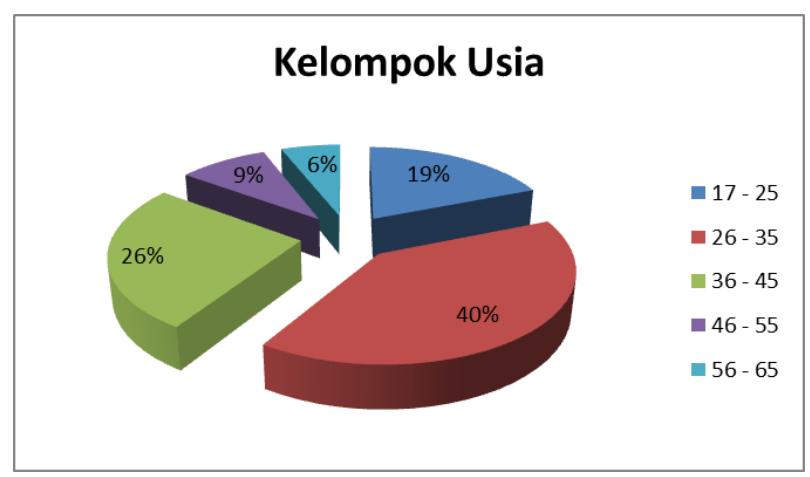

Gambar 4 Karakteristik responden berdasarkan usia

Responden pada penelitian ini sangat luas yang dikelompokkan menurut jenis pekerjaan, yaitu: Mahasiswa, Pedagang, Pengusaha, Karyawan, Satpam, dan Tukang Becak. Mahasiwa yang dimaksud adalah mahasiswa yang tinggal atau beraktifitas di Kampoeng Batik Laweyan. Pedagang merupakan pedagang makanan dan minuman yang ada di Kampoeng Batik Laweyan. Pengusaha adalah pengusaha batik yang bertempat tinggal dan memiliki showroom di Kampoeng Batik Laweyan. Karyawan adalah penunggu showroom dan pekerja batik yang bekerja dan bertempat tinggal di Kampoeng Batik Laweyan. Satpam merupakan tenaga pengamanan yang bekerja di showroom Kampoeng Batik Laweyan. Tukang becak adalah tukang becak yang bekerja di Kampoeng Batik Laweyan untuk mengantar para wisatawan. 


\section{Teknik, 38 (1), 2017, 32}

\subsection{Uji Validitas dan Realiabilitas}

Hasil pengujian validitas menunjukkan bahwa nilai $r$ hitung lebih besar daripada $r$ tabel yang berarti semua pertanyaan pada penelitian ini bersifat valid.

Hasil pengujian reliabilitas variabel desa wisata pada Tabel 3 menunjukkan nilai Cronbach's Alpha sebesar 0,777. Nilai tersebut lebih besar dari 0,60 sehingga variabel ini reliabel atau dapat dipercaya.

Tabel 3 Uji Reliabilitas Variabel Desa Wisata

\section{Reliabi lity Statistics}

\begin{tabular}{|c|r|}
\hline $\begin{array}{c}\text { Cronbach's } \\
\text { Alpha }\end{array}$ & $\mathrm{N}$ of Items \\
\hline, 777 & 18 \\
\hline
\end{tabular}

Hasil pengujian variabel fungsi permukiman pada Tabel 4 menunjukkan nilai Cronbach's Alpha sebesar 0,634 . Nilai tersebut lebih besar dari 0,60 sehingga variabel tersebut reliabel atau dapat dipercaya.

Tabel 4 Uji Reliabilitas Variabel Fungsi Permukiman

\begin{tabular}{|r|r|}
\hline Cronbach's Alpha & \multicolumn{2}{|c|}{ N of Items } \\
\hline, 634 & 11 \\
\hline
\end{tabular}

3.3 Analisis Pengaruh Desa Wisata Kampoeng Batik Laweyan terhadap Fungsi Permukiman di Kelurahan laweyan Kota Surakarta

\subsubsection{Koefisien Determinasi dan Korelasi}

Berdasarkan tabel output model summary pada Tabel 5, dapat disimpulkan bahwa nilai koefisien korelasi (R) adalah sebesar 0,903 yang berarti bahwa desa wisata Kampoeng Batik Laweyan memiliki hubungan yang kuat dengan fungsi permukiman di Kelurahan Laweyan. Sedangkan untuk nilai koefisien determinasi $\left(\mathrm{R}^{2}\right)$ adalah sebesar 0,816 yang artinya desa wisata Kampoeng Batik Laweyan memiliki pengaruh terhadap fungsi permukiman di Kelurahan Laweyan sebesar 81,6 \% sedangkan sisanya sebesar $18,4 \%$ dipengaruhi faktor lainya diluar model .

Tabel 5 Model Summary Pengaruh X terhadap Y Model Summary

\begin{tabular}{|l|r|r|r|r|}
\hline Model & \multicolumn{1}{|c|}{$\mathrm{R}$} & $\mathrm{R}$ Square & $\begin{array}{c}\text { Adjusted } \\
\text { R Square }\end{array}$ & $\begin{array}{c}\text { Std. Error of } \\
\text { the Estimate }\end{array}$ \\
\hline 1 &, $903^{\mathrm{a}}$ &, 816 &, 806 &, 114 \\
\hline
\end{tabular}

a. Predictors: (Constant), X5, X4, X1, X3, X2

\subsubsection{Analisis Deskriptif Uji Regresi X terhadap Y}

Pengaruh desa wisata Kampoeng Batik Laweyan terhadap fungsi permukiman di Kelurahan Laweyan Kota Surakarta adalah sebesar $81,6 \%$. Pengaruh tersebut meliputi aksesibilitas, atraksi, amenity, ancilliary serta aktifitas. Semua variabel tersebut setelah dilakukan uji koefisien determinasi dengan didapatkan pengaruh yang cukup besar dan cukup signifikan. Keberadaan variabelvariabel tersebut sebagai penunjang pengembangan desa wisata dan pariwisata berkelanjutan yang ada di Kelurahan Laweyan. Aksesbilitas, atraksi wisata, amenity, anciliary serta aktifitas mempengaruhi fungsi permukiman di Kelurahan Laweyan dan pengaruhnya seperti perubahan fungsi permukiman dari yang awalnya hunian sekarang menjadi hunian, tempat usaha serta ruang untuk fasilitas pendukung lainnya seperti jalan yang berubah menjadi lahan parkir, koridor jalan yang dirubah sebagai tempat atraksi wisata, dan beberapa hal penting yaitu perubahan pada fungsi ruang rumah para pedagang batik.

Sedangkan sisanya $18,4 \%$ dipengaruhi oleh faktor lainnya yaitu sejawah kawasan Laweyan sendiri yang sejak dahulu merupakan kawasan sentra batik kemudian seiring dengan perubahan morfologi yang terjadi tidak lepas dari aktifitas pendukung wisata di Kelurahan laweyan karena adanya keterkaitan antara fasilitas ruangruang di Kelurahan Laweyan dengan seluruh kegiatan yang ada di Kelurahan Laweyan. Keberadaan kegiatan pendukung di Kelurahan Laweyan. Kegiatan pendukung di Kelurahan Laweyan seperti pentas seni budaya, ketersediaan belajar membatik untuk para wisatawan serta kegiatan budaya lainnya mulai muncul dan tumbuh sehingga fungsi ruang untuk kegiatan pendukung tersebut juga ikut bertumbuh.

Perubahan tata guna lahan. Berdasarkan RTRW Kota Surakarta Tahun 2011-2031 Kecamatan Laweyan dengan luas $111 \mathrm{Ha}$ diperuntukkan menjadi kawasan permukiman berkepadatan tinggi, dan $1 \mathrm{Ha}$ sebagai kawasan perdagangan meliputi pusat perbelanjaan dan pertokoan modern serta pasar tradisional. Selain itu Kecamatan Laweyan juga diperuntukkan sebagai pariwisata budaya, olahraga, dan industri kreatif. Akan tetapi pada kenyataanya di Kelurahan Laweyan kawasan permukiman dengan berkepadatan rendah dikarenakan luas rumah yang dimiliki masyarakat Kelurahan laweyan sangat besar sehingga selain diperuntukkan sebagai permukiman dan perdagangan dan jasa Kelurahan Laweyan juga berubah fungsi menjadi kawasan industri dengan skala besar. Kemudian di Kelurahan Laweyan sendiri minim sekali lapangan atau fasilitas olahraga, yang dimiliki hanya balai desa atau balai pertemuan yang kadang dipergunakan untuk berolahraga itupun hanya tenis meja, untuk lapangan basket sendiri yang berada di Kelurahan Laweyan milik Pemda tetapi saat ini difungsikan sebagai tempat parkir.

\subsubsection{Uji Simultan (Uji F)}

Dari hasil uji simultan yang ditampilkan Tabel 6 diketahui nilai $\mathrm{F}$ hitung sebesar 83,487 dengan nilai Sig sebesar 0,000 sedangkan nilai $\mathrm{F}$ tabel berdasarkan tabel distribusi F dengan taraf siginfikansi 5\% $(0,05)$ untuk 100 
Teknik, 38 (1), 2017, 33

responden dengan 6 variabel pengujian adalah sebesar 2.19. maka didapatkan hasil $\mathrm{F}$ hitung $(83,487)>\mathrm{F}$ tabel $(2,19)$ dan nilai $\operatorname{Sig}(0,000)>0,05$. Sesuai dengan kriteria pengujian yang ada maka dapat disimpulkan bahwa variabel Desa Wisata Kampoeng Batik Laweyan berpengaruh terhadap variabel fungsi permukiman di Kelurahan Laweyan.

Tabel 6 Tabel ANOVA Pengaruh X terhadap Y ANOVA

\begin{tabular}{|c|c|c|c|c|c|c|}
\hline \multicolumn{2}{|c|}{ Model } & $\begin{array}{l}\text { Sum of } \\
\text { Squares }\end{array}$ & df & Mean Square & $\mathrm{F}$ & Sig. \\
\hline \multirow[t]{3}{*}{1} & Regression & 5,409 & 5 & 1,082 & 83,487 &, $000^{2}$ \\
\hline & Residual & 1,218 & 94 &, 013 & & \\
\hline & Total & 6,628 & 99 & & & \\
\hline
\end{tabular}

a. Predictors: (Constant), X5, X4, X1, X3, X2

b. Dependent Variable: $Y$

\subsubsection{Uji Parsial (Uji T)}

Hasil uji parsial ditunjukkan Tabel 7. Hasil uji ini memberikan nilai 0,168 pada koefisien regresi variabel aksesibilitas (X1) bernilai positif yang berarti menunjukkan hubungan positif antara variabel aksesibilitas dan variabel fungsi permukiman. Semakin tinggi nilai variabel aksesibilitas, maka semakin tinggi nilai variabel dari fungsi permukiman.

Nilai 0,222 pada koefisien regresi variabel attraction (X2) bernilai positif yang berarti menunjukkan hubungan positif antara variabel attraction dan variabel fungsi permukiman. Semakin tinggi nilai variabel attraction, maka semakin tinggi nilai variabel dari fungsi permukiman.

Nilai 0,260 pada koefisien regresi variabel amenity (X3) bernilai positif yang berarti menunjukkan hubungan positif antara variabel amenity dan variabel fungsi permukiman. Semakin tinggi nilai variabel amenity, maka semakin tinggi nilai variabel dari fungsi permukiman.

Nilai 0,022 pada koefisien regresi variabel ancilliary (X4) bernilai positif yang berarti menunjukkan hubungan positif antara variabel ancilliary dan variabel fungsi permukiman. Semakin tinggi nilai variabel ancilliary, maka semakin tinggi nilai variabel dari fungsi permukiman.

Nilai 0,139 pada koefisien regresi variabel aktivitas (X5) bernilai positif yang berarti menunjukkan hubungan positif antara variabel activity dan variabel fungsi permukiman. Semakin tinggi nilai variabel activity, maka semakin tinggi nilai variabel dari fungsi permukiman

Tabel 7 Uji parsial (T) Pengaruh X terhadap Y

\begin{tabular}{|c|c|c|c|c|c|}
\hline \multirow{2}{*}{ Variabel } & \multicolumn{2}{|c|}{ Nilai $T$} & \multicolumn{2}{|c|}{ Nilai Sig. } & \multirow{2}{*}{ Kesimpulan } \\
\hline & T hitung & $T$ tabel & Sig. & $\alpha$ & \\
\hline $\begin{array}{l}\text { Accesbility } \\
\text { (X1) }\end{array}$ & $2,787>$ & 1,660 & 0,006 & 0,05 & $\begin{array}{l}\text { Pengaruh X1 } \\
\text { terhadap Y } \\
\text { signifikan }\end{array}$ \\
\hline
\end{tabular}

\begin{tabular}{|l|lll|lll|l|}
\hline \multicolumn{1}{|c|}{ Variabel } & \multicolumn{2}{|c|}{ Nilai T } & \multicolumn{2}{c|}{ Nilai Sig. } & Kesimpulan \\
\hline $\begin{array}{l}\text { Attraction } \\
(\mathrm{X})\end{array}$ & 2,238 & $>$ & 1,660 & 0,028 & $<$ & 0,05 & $\begin{array}{l}\text { Pengaruh X2 } \\
\text { terhadap Y } \\
\text { signifikan }\end{array}$ \\
\hline $\begin{array}{l}\text { Amenity } \\
(\mathrm{X} 3)\end{array}$ & 3,944 & $>$ & 1,660 & 0,000 & $<$ & 0,05 & $\begin{array}{l}\text { Pengaruh X3 } \\
\text { terhadap Y } \\
\text { signifikan }\end{array}$ \\
\hline $\begin{array}{l}\text { Ancilliary } \\
(\mathrm{X} 4)\end{array}$ & 0,891 & $<$ & 1,660 & 0,375 & $>$ & 0,05 & $\begin{array}{l}\text { Pengaruh X4 } \\
\text { terhadap Y } \\
\text { tidak } \\
\text { signifikan }\end{array}$ \\
\hline $\begin{array}{l}\text { Activity } \\
\text { (X5) }\end{array}$ & 3,352 & $>$ & 1,660 & 0,001 & $<$ & 0,05 & $\begin{array}{l}\text { Pengaruh X5 } \\
\text { terhadap Y } \\
\text { signifikan }\end{array}$ \\
\hline
\end{tabular}

3.4 Analisis Pengaruh Desa Wisata Kampoeng Batik Laweyan $(\mathrm{X})$ terhadap Masing-masing Variabel dari Fungsi Permukiman (Y) di Kelurahan laweyan Kota Surakarta

3.4.1 Pengaruh Desa Wisata Kampoeng Batik Laweyan (X) terhadap Ruang Interaksi (Y1)

Output Model Summary yang dimuat Tabel 8 menunjukkan nilai koefisien korelasi (R) sebesar 0,703 yang berarti bahwa variabel desa wisata Kampoeng Batik Laweyan memiliki hubungan yang erat dengan ruang interaksi sosial. Nilai koefisien determinasi $\left(\mathrm{R}^{2}\right)$ adalah 0,494 menunjukkan bahwa variabel desa wisata Kampoeng Batik Laweyan mempunyai pengaruh terhadap ruang interaksi sosial sebesar $49,4 \%$ sedangkan sisanya sebesar 50,6\% dipengaruhi faktor lainnya di luar model.

Tabel 8 Tabel ANOVA Pengaruh X terhadap Y1 Model Summary

\begin{tabular}{|l|r|r|r|r|}
\hline Model & \multicolumn{1}{|c|}{$\mathrm{R}$} & $\mathrm{R}$ Square & $\begin{array}{c}\text { Adjusted } \\
\text { R Square }\end{array}$ & $\begin{array}{c}\text { Std. Error of } \\
\text { the Estimate }\end{array}$ \\
\hline 1 &, $703^{\mathrm{a}}$ &, 494 &, 467 &, 215 \\
\hline
\end{tabular}

a. Predictors: (Constant), X5, X4, X1, X3, X2

3.4.2 Pengaruh Desa Wisata Kampoeng Batik Laweyan (X) terhadap Ruang Atraksi Wisata (Y2)

Output Model Summary pada Tabel 9 menunjukkan bahwa nilai koefisien korelasi (R) adalah 0,898 yang berarti bahwa variabel desa wisata Kampoeng Batik Laweyan memiliki hubungan yang erat dengan ruang atraksi wisata. Kemudian nilai koofisien determinasi $\left(\mathrm{R}^{2}\right)$ sebesar 0,806 menunjukkan bahwa variabel desa wisata Kampoeng Batik Laweyan mempunyai pengaruh terhadap ruang atraksi wisata sebesar $80,6 \%$ sedangkan sisanya sebesar $19,4 \%$ dipengaruhi faktor lainnya di luar model.

Tabel 9 Tabel ANOVA Pengaruh X terhadap Y2

\begin{tabular}{|l|r|r|r|r|}
\multicolumn{7}{c|}{ Model Summary } \\
\hline Model & $\mathrm{R}$ & $\mathrm{R}$ Square & $\begin{array}{c}\text { Adjusted } \\
\text { R Square }\end{array}$ & $\begin{array}{c}\text { Std. Error of } \\
\text { the Estimate }\end{array}$ \\
\hline 1 &, $898^{\mathrm{a}}$ &, 806 &, 796 &, 117 \\
\hline
\end{tabular}

a. Predictors: (Constant), X5, X4, X2, X3, X1 


\section{Teknik, 38 (1), 2017, 34}

3.4.3 Pengaruh Desa Wisata Kampoeng Batik Laweyan (X) terhadap Ruang Aktifitas (Y3)

Output Model Summary yang ditunjukkan Tabel 10 memberikan nilai koefisien korelasi (R) sebesar 0,925 yang berarti bahwa variabel desa wisata Kampoeng Batik Laweyan memiliki hubungan yang erat dengan ruang aktifitas. Kemudian nilai koofisien determinasi $\left(\mathrm{R}^{2}\right)$ sebesar 0,855 menunjukkan bahwa variabel desa wisata Kampoeng Batik Laweyan mempunyai pengaruh terhadap ruang aktifitas sebesar $85,5 \%$ sedangkan sisanya sebesar $14,5 \%$ dipengaruhi faktor lainnya di luar model.

Tabel 10 Tabel ANOVA Pengaruh X terhadap Y3 Model Summary

\begin{tabular}{|l|r|r|r|r|}
\hline Model & $\mathrm{R}$ & $\mathrm{R}$ Square & $\begin{array}{c}\text { Adjusted } \\
\text { R Square }\end{array}$ & $\begin{array}{r}\text { Std. Error of } \\
\text { the Est imate }\end{array}$ \\
\hline 1 &, $925^{\mathrm{a}}$ &, 855 &, 847 &, 124 \\
\hline
\end{tabular}

a. Predictors: (Constant), X5, X4, X1, X3, X2

3.4.4 Pengaruh Desa Wisata Kampoeng Batik Laweyan (X) terhadap Ruang Pendukung Wisata (Y4)

Output Model Summary pada Tabel 11 menunjukkan bahwa nilai koefisien korelasi (R) sebesar 0,853 yang berarti bahwa variabel desa wisata Kampoeng Batik Laweyan memiliki hubungan yang erat dengan ruang pendukung wisata. Kemudian nilai koofisien determinasi $\left(\mathrm{R}^{2}\right)$ sebesar 0,728 menunjukkan bahwa variabel desa wisata Kampoeng Batik Laweyan mempunyai pengaruh terhadap ruang pendukung wisata sebesar $72,8 \%$ sedangkan sisanya sebesar 27,2\% dipengaruhi faktor lainnya di luar model.

Tabel 11 Tabel ANOVA Pengaruh X terhadap Y4 Model Summary

\begin{tabular}{|l|r|r|r|r|}
\hline Model & $\mathrm{R}$ & $\mathrm{R}$ Square & $\begin{array}{c}\text { Adjusted } \\
\mathrm{R} \text { Square }\end{array}$ & $\begin{array}{c}\text { Std. Error of } \\
\text { the Estimate }\end{array}$ \\
\hline 1 &, $853^{\mathrm{a}}$ &, 728 &, 713 &, 162 \\
\hline
\end{tabular}

a. Predictors: (Constant), X5, X4, X1, X3, X2

\subsection{Kesimpulan}

Berdasarkan hasil analisis yang dilakukan, desa wisata Kampoeng Batik Laweyan memberikan pengaruh terhadap perubahan fungsi permukiman di Kelurahan Laweyan sebesar $81,6 \%$ sedangkan sisanya 18,4\% dipengaruhi oleh faktor lain di luar model yaitu sejarah kawasan dan perubahan tata guna lahan. Variabel yang paling berpengaruh terhadap fungsi permukiman adalah accesbility, attraction, amenity serta activity. Secara keseluruhan semua variabel berpengaruh terhadap fungsi permukiman. Satu variabel yang pengaruhnya tidak signifikan terhadap fungsi permukiman adalah anciliary atau kelembagaan.
Pengaruh desa wisata Kampoeng Batik Laweyan terhadap fungsi permukiman adalah terjadinya beberapa perubahan-perubahan fungsi ruang yaitu balai pertemuan atau balai desa sebagian difungsikan sebagai tempat untuk olahraga tennis meja, koridor jalan difungsikan sebagai tempat atraksi kebudayaan, lapangan basket milik Pemda difungsikan sebagai tempat parkir, serta bahu jalan difungsikan sebagai tempat parkir sehingga menganggu mobilitas pergerakan barang dan manusia. Perubahan tata guna lahan sendiri yang awalnya diperuntukkan sebagai kawasan permukiman berkepadatan tinggi menjadi kawasan industri kreatif berskala besar, ruang terbuka seperti makam yang memiliki seikit openspace kini dijadikan sebagai pujasera serta jalur pedestrian di fungsikan sebagai warung makan. Kemudian di desa wisata Kampoeng Batik Laweyan juga terjadi penambahan street furniture seperti bangku, lampu, tugu, papan peta mapping, papan informasi zonasi kawasan Kampoeng Batik Laweyan serta gerbang masuk desa wisata Kampoeng Batik Laweyan yang semuanya berornamen batik agar menjadi ciri khas kawasan desa wisata Kampoeng Batik Laweyan. Sinergi antara stake holder yang terkait seperti pemerintah, swasta, dan masyarakat sangat diperlukan dalam pengembangan desa wisata ini.

\section{Daftar Pustaka}

Adisasmita, R. (2010). Pembangunan Kawasan dan Tata Ruang. Yogyakarta: Graha Ilmu.

Bintarto, R. (1983). Interaksi Desa-Kota dan Permasalahannya. Yogyakarta: Ghalia Indonesia Yogyakarta

Direktorat Jenderal Cipta Karya. (1998). Kamus Tata Ruang. Jakarta: Departemen Pekerjaan Umum

Jayadinata, Djohara, T. (1992). Tata Guna Tanah Dalam Perencanaan Pedesaan, Perkotaan, dan Wilayah. Bandung: ITB.

Pemerintah Daerah Kota Surakarta. (2012). Peraturan Daerah Kota Surakarta No. 1 Tahun 2012 tentang Rencana Tata Ruang Wilayah Kota Surakarta Tahun 2012-2031. Lembaran daerah Kota Surakarta tahun 2012, No. 1. Sekretaris Daerah. Surakarta

Republik Indonesia. (2009). Undang-Undang No. 10 Tahun 2009 tentang Kepariwisataan. Lembaran Negara RI Tahun 2009, No. 11. Sekretariat Negara. Jakarta.

Yudohusodo, Siswono, dkk. (1991). Rumah untuk Seluruh Rakyat. INKOPPOL: Jakarta.

Hadi, S. Yunus (2000). Struktur Tata Ruang Kota. Yogyakarta: Penerbit Pustaka Pelajar. 